\title{
EVALUASI PROGAM E-LEARNING BAGI PETUGAS LAPANGAN
}

\author{
Sridadi Pudjo Suparto \\ FIP Universitas Negeri Jakarta (email: sridadisuparto@yahoo.com)
}

\begin{abstract}
Abstrak: Evaluasi Program E-Learning bagi Petugas Lapangan. Penelitian ini bertujuan untuk meningkatkan efektivitas pengembangan e-learning dalam program KB dengan menggunakan model evaluasi Context, Input, Process, Product (CIPP) oleh Stufflebeam. Data yang diperoleh dengan menggunakan guided interview, focus group discussion dan studi dokumentasi tentang pengembangan e-learning. Hasil penelitian menunjukkan hal-hal sebagai berikut. (1) Prinsip-prinsip dan rasional mengapa e-learning perlu dibangun dalam sistem belajar program $\mathrm{KB}$ telah dapat diidentifikasi dan telah dapat dibuktikan kesiapan tentang sistem dan komitmen yang mendukung pengembangan e-learing tersebut. (2) Penyesuaianpenyesuaian perlu dilakukan dalam sistem pelatihan, aplikasi dari organisasi belajar, tim pengembang e-learning, strategi e-learning, desain dan standard bahan pembelajaran, jaringan, bandwith, peralatan, serta dana untuk mendukung proses interaktif dalam belajar. (3) Perlu pemahaman dari organisasi tentang diperlukannya dukungan tambahan jaringan dan bandwith dalam belajar. (4) Perlu pemahaman dari sistem lokal tentang faktor-faktor teknis untuk memperbaiki proses belajar, meningkatkan kecepatan, dan menghindari masalah-masalah teknis yang lain selama proses interaksi.
\end{abstract}

Kata Kunci: e-learning, pengembangan, evaluasi

Abstract: An Evaluation of the E-learning Program for Field Workers. This study was aimed to improve the effectiveness of the e-learning development in the family planning program using the CIPP evaluation model.The data were collected through guided interviews, focus group discussion and documentation. The findings of the study showed the followings. (1) The principles and rationales of the e-learning development could be identified from the readiness of the system and the commitment to support the e-learning development, (2) Adjustments needed to be done in the training system, the application of the learning organization, the e-learning development team, e-learning strategies, the design and standard of the teaching materials, the network, bandwidth, equipment, and budget to support the interactive process in learning. (3) The organization needed to understand about the required support in the form of extra network and bandwidth. (4) The local system needed to understand about the technical factors to improve the learning process, the speed, and to avoid other technical problems in the interaction process.

Keywords: e-learning, development, evaluation 


\section{PENDAHULUAN}

Perubahan besar dalam kewenangan dan organisasi di era desentralisasi telah berpengaruh pada perubahan sistem pembelajaran bagi sumber daya manusia di kabupaten/kota. Berbagai persepsi yang berbeda tentang pentingnya KB telah menjadi satu gambaran yang umum terjadi sampai dengan saat ini. Bagaimana pemerintah daerah menyikapi pentingnya $\mathrm{KB}$ pada wilayah kerjanya sangat berpengaruh pada kehendak pemerintah daerah memfasilitasi program tersebut. Adapun perkembangan pembangunan KB menurut SDKI (Sensus Demografi dan Kesehatan Indonesia) pada tahun 2007 telah terjadi penurunan Angka Kelahiran Total (Total Fertility Rate/TFR) dari 2,4 (SDKI 2002/2003) menjadi sekitar 2,3 anak per perempuan usia reproduksi (SDKI 2007).

Dari hasil SDKI tahun 2007 tersebut, berarti telah terjadi satu perkembangan yang tidak menguntungkan bagi pencapaian program KB karena walaupun TFR cenderung menurun namun tingkatnya belum mencapai sasaran ideal, yakni TFR 2,1. Menanggapi kondisi program KB di era desentralisasi ini Presiden dalam pembahasan program tahun 2009 menyatakan program KB harus direvitalisasi dan harus didukung dengan dana yang cukup untuk mensukseskan. Capacity building bagi para petugas yang bekerja di tingkat lapangan telah disepakati dan menjadi perhatian utama. Dalam kaitan dengan kebijakan ini, telah dibangun strategi belajar dengan memanfaatkan teknologi yang semakin canggih dan infrastruktur yang telah tersedia di lingkungan internal program KB sendiri.

Pendekatan E-learning telah dikaji manfaatnya sejak tahun 2007. Dalam kurun waktu tiga tahun pengembangannya sudah saatnya dievaluasi untuk tujuan perbaikan efisiensi dan efektivitas program E-learning yang sedang dikembangkan. Perubahan dan penyesuaian dengan lingkungan eksternal yang berubah tidaklah dapat dilakukan dalam waktu yang singkat. Namun, ada satu kunci untuk kecepatan mengadopsi perubahan itu sendiri. Salah satunya adalah telah berlangsungnya budaya belajar. Organisasibelajar (learning organization) dengan berbagai prinsip dan kiat-kiat bagaimana melaksanakannya dalam satu organisasi adalah salah satu kunci kecepatan diadopsinya satu perubahan dalam organisasi. Pendekatan pembelajaran E-learning bagaimanapun memerlukan budaya belajar bagi para petugas KB yang dalam tahap awal era desentralisasi telah dipersiapkan untuk terbiasa dengan belajar mandiri.

Dalam kaitannya membangun strategi pembelajaran, belajar lebih diartikan sebagai pengetahuan yang diperoleh melalui belajar sendiri (self directed study), pengalaman atau melalui baik dengan kiat memperoleh pengetahuan, keterampilan, kompetensi, sikap, dan ide yang dikumpulkan dan kemudian digunakan, atau diartikan sebagai satu perubahan perilaku melalui pengalaman (Illey dan Maycunich, 2000:207). Dalam belajar yang bermuara pada perilaku, belajar yang demikian melibat- 
kan satu perubahan. Belajar yang sebenarnya terjadi adalah pada saat menghasilkan satu tindakan yang dapat didemonstrasikan apabila perilaku berubah (Gilley dan Maycunich, 2000: 207). Dari pengertian ini dapat disimpulkan bahwa belajar berdampak pada perubahan, sehingga dengan berjalannya waktu akan meningkatkan kapasitas kinerja seseorang.

Pendapatlaindinyatakan oleh Senge (1990:191) yang mempercayai bahwa belajar hanya sedikit bersentuhan dengan informasi yang diperoleh seseorang, tetapi lebih kepada pengertian bahwa ia merupakan satu proses untuk meningkatkan kemampuan. Belajar adalah membangun kemampuan untuk menciptakan (create) yang sebelumnya tidak dimiliki. Ia sangat terkait dengan tindakan. Dalam sebuah organisasi yang berkembang, proses belajar dan berubah akan meningkatkan kapasitas individu dan kemampuan para pegawai, sehingga organisasi atau perusahaan akan berada dalam posisi yang senantiasa tumbuh dan berkembang.

Banyak model evaluasi yang dapat digunakan untuk mengakses keberhasilan satu pembelajaran. Oleh karena sifat dari E-learning dalam sistem pendidikan dan pelatihan (diklat) KB yang mempunyai perspektif sangat luas dan mencakup berbagai aspek yang mempengaruhi keberhasilannya, maka studi ini memilih Evaluasi Stufflebeam yang dalam menilai keberhasilan pembelajaran mencakup wilayah Context, Input, Process dan Product (CIPP). Evaluasi produk tidak dilakukan dalam evaluasi proses pengembangan E-learning ini karena tahap pengembangan belum sampai menghasilkan produk akhir sebagaimana yang diharapkan. Model evaluasi CIPP ini bertujuan untuk memperoleh informasi yang bertujuan untuk memberikan masukan kepada pemegang kebijakan dalam pengambilan keputusan terhadap program pengembangan E-learning selanjutnya. Pada dasarnya model CIPP mempunyai pembelajaran yang sangat mendasar bahwa tujuan utama suatu evaluasi adalah bukan membuktikan tetapi untuk memperbaiki.

Pernyataan ini dikemukakan oleh Egon Guba pada Phi Delta Kappa National Study Committee on Evaluation (Stufflebeam, 2007:331) Dikatakan lebih lanjut bahwa evaluasi sebagaimana pada konsep awalnya adalah kegiatan yang secara fungsional berorientasi jangka panjang untuk menstimulasi dan memberikan bantuan terhadap upaya memperkuat dan meningkatkan kualitas perusahaan atau organisasi. Model ini juga menekankan bahwa beberapa program yang akan terbukti tidak bermanfaat untuk diperbaiki, harus dihilangkan atau tidak dihiraukan. Dengan memberibantuan denganmenghentikan yang tidak perlu, salah kelola, tidak efisien, atau upaya yang tidak akan menghasilkan apa-apa, maka evaluasi akan menjalankan fungsi advisory peningkatan mutunya melalui perbantuan waktu dan daya serta dana yang tidak banyak untuk upaya-upaya yang manfaat. Model CIPP juga mewajibkan para evaluator untuk mengidentifikasi dan membuat laporan pembelajaran yang berharga baik tentang upaya yang sukses maupun yang gagal. 
Stufflebeam, 2007:335) menyatakan bahwa tujuan evaluasi konteks adalah untuk menggambarkan konteks yang relevan, mengidentifikasi target populasi dan menilai kebutuhan-kebutuhannya, mengidentifikasi peluang untuk memenuhi kebutuhan, mendiagnosa permasalahan yang mendasari kebutuhan, dan menilai apakah sasaran program cukup sesuai dengan kebutuhan yang telah dinilai. Evaluasi ini bisa dilakukan sebelum, selama, atau bahkan setelah suatu program atau proyek dilaksanakan, atau intervensi lain. Rekomendasi hasil evaluasi bisa tetap mempertahankan apa yang ada sekarang, perlu memodifikasi atau menyusun kembali rasional, asumsi, dan tujuan-tujuan yang baru karena dinilai sudah tidak relevan (Stufflebeam, 2007: 338). Stufflebeam menyatakan bahwa evaluasi input secara keseluruhan bertujuan untuk membantu pembuat keputusan menguji strategi alternatif untuk mengakomodasikan kebutuhan-kebutuhan yang ditetapkan, menyusun rencana yang dapat dilaksanakan dan anggaran yang tepat, dan mengembangkan catatan pertanggungjawaban untuk mempertahankan prosedurnya dan sumber daya yang direncanakan.

Orientasi utama dari evaluasi input adalah untuk membantu menentukan suatu program dalam membuat perubahan yang diperlukan. Fungsi penting yang lain untuk membantu para pemimpin program menghindari praktek yang memboroskan mengetahui inovasi-inovasi yang akan gagal atau menyia-nyiakan sumber daya dan kemudian menemukan solusinya. Evaluasi ini dilakukan dengan mencari sam- pai dapat dan kritis menguji pendekatan yang secara potensial relevan, termasuk yang telah digunakan. Lebih lanjut tentang evaluasi proses, Stufflebeam, et al. (2007:335) menyatakan bahwa evaluasi ini merupakan pemeriksaan yang berkelanjutan terhadap suatu rencana yang diimplementasikan dari suatu dokumentasi proses.Tujuan evaluasi proses, yaitu untuk menguji sejauhmana aktivitas-aktivitas dalam suatu program telah dilaksanakan sesuai berdasarkan jadwal, rencana, anggaran, dan efisiensinya.

Dari latar belakang tersebut, maka melalui penelitian ini diharapkan dapat diperoleh jawaban terhadap pertanyaan, antara lain sebagai berikut. Dalam kaitan konteks meliputi hal-hal seperti berikut. (1) Apa saja landasan yang mendasari pengembangan E-learning bagi petugas lapangan KB? (2) Apakah tujuan pengembangan E-learning relevan dengan kebutuhan? (3) Apa saja dasar pertimbangan (rasional) mengapa E-learning perlu dikembangkan dalam program KB? Dalam kaitan dengan input meliputi: (1) bagaimana perencanaan sumber daya manusia (SDM) baik kualifikasi peserta maupun pengembang dalam pengembangan $E$ learning? (2) Bagaimana kemampuan sistem diklat dalam pengembangan $E$ learning?, (3) Bagaimana prosedur pengembangan dan pelaksanaan E-learning?, (4) Bagaimana perencanaan sarana dan prasarana serta anggaran dalam pengembangan dan pelaksanaan $E$ learning?; Dalam kaitan dengan proses meliputi: (1) Bagaimana kesesuaian antara pelaksanaan kualifikasi SDM (peserta dan pengembang) dengan peren- 
canaannya? (2) Bagaimana kesesuaian antara pelaksanaan E-learning dengan perencanaan E-learning? (3) Bagaimana kesesuaian anggaran dan jadwal dalam perencanaan dan pelaksanaan E-learning?

\section{METODE}

Penelitian ini melakukan kajian evaluasi pengembangan program Elearning pada komponen konteks, input, dan proses untuk memperoleh informasi agar dapat dilakukan perbaikan-perbaikan pada proses pengembangan E-learning dan pelaksanaannya. Informasi tersebut digunakan sebagai bahan pertimbangan untuk pemegang kebijakan dalam pengambilan keputusan terhadap program pengembangan dan pelaksanaan E-learning selanjutnya. Pada komponen konteks diharapkan dapat diperoleh informasi mengenai (1) landasan-landasan yang mendasari pengembangan E-learning bagi petugas lapangan $\mathrm{KB}$; (2) relevansi tujuan pengembangan E-learning terhadap kebutuhan; dan (3) rasional pengembangan E-learning; komponen input untuk memperoleh informasi tentang (a) perencanaan SDM (kualifikasi peserta dan pengembang), kemampuan sistem diklat, prosedur pengembangan dan pelaksanaan E-learning sehingga dapat menentukan perubahan dan solusi yang diperlukan, serta (b) memperoleh informasi tentang perencanaan sarana dan prasarana serta anggaran dalam pengembangan dan pelaksanaan Elearning agar dapat menghindari praktek yang memboroskan; dan komponen proses untuk memperoleh informasi mengenai (a) kesesuaian antara pelak- sanaan kualifikasi SDM (peserta dan pengembang) dengan perencanaannya?, (b) kesesuaian antara pelaksanaan E-learning dengan perencanaan Elearning?, dan (c) kesesuaian anggaran dan jadwal dalam perencanaan dan pelaksanaan E-learning?

Kriteria penelitian dalam evaluasi ini adalah standar kesesuaian (Miarso, 2004:207). Artinya, pengukuran dalam evaluasi program ini dilakukan dengan membandingkan antara kenyataan yang ada dalam pelaksanaan program dengan ukuran atau kriteria tentang bagaimana seharusnya pelaksanaan program itu terjadi. Penelitian ini dilaksanakan pada bulan November sampai dengan Desember 2010 dengan menggunakan metode penelitian kualitatif dengan dua jenis data, yaitu data primer dan data sekunder. Data primer diperoleh melalui wawancara dengan para informan dan focus group discussion (FGD) untuk mendapatkan data yang berkaitan dengan pengembangan E-learning. Data sekunder diperoleh dari berbagai publikasi dan dokumen yang relevan baik dari BKKBN Pusat maupun P r o v i n s i/Kabupaten/Kota. Sumber data dalam penelitian ini adalah pimpinan-pimpinan dan para staf Pusat Pendidikan, Direktorat Informasi, Direktorat Teknik, dan Pengembang E-learning mencakup tim desainer Elearning dan widyaiswara. Pada evaluasi konteks data yang dikumpulkan berupa dokumen dan wawancara, evaluasi input data berupa dokumen dan wawancara, dan evaluasi proses data berupa wawancara dan FGD. 
HASIL

\section{Evaluasi Konteks (Context Evaluation)}

Evaluasi konteks yang dikaji dalam penelitian ini meliputi landasan, tujuan, dan rasional pengembangan $E$ learning bagi Petugas Lapangan.

\section{Landasan Pengembangan E-learning Bagi Petugas Lapangan}

Landasan pengembangan E-learning bagi petugas lapangan telah ada, antara lain dengan dikeluarkannya Surat Keputusan Kepala BKKBN tentang Pembentukan Kelompok Kerja Pengembangan Layanan Informasi Berbasis Teknologi Informasi Suatu Model Percepatan Pemberdayaan PKB/PLKB melalui Pembelajaran Jarak Jauh di Lingkungan BKKBN dan Peraturan Kepala BKKBN tentang Pengelolaan Pengembangan Kapasitas Tenaga Program Keluarga Berencana dan Keluarga Sejahtera di Kabupaten dan Kota melalui E-learning. Dua landasan formal pendekatan E-learning bagi petugas KB di kabupaten/kota tersebut merupakan dua sumber hukum yang menaungi legalitas, tujuan, dan ruang lingkup serta hubungan kerja.

Dari analisis terhadap kedua landasan formal di atas dapat disimpulkan bahwa pengembangan telah mempunyai tujuan serta ruang lingkup baik sasaran dan jangkauan yang jelas. Namun demikian, diperlukan ketentuan yang mengatur bahwa pembelajaran menjadi inti kegiatan yang dilakukan oleh bidang Pelatihan, yang didukung oleh teknis jaringan dan informasi yang merupakan dasar hukum dan kebijakan agar pusat pelatihan mampu mengelola strategi pembelajaran dengan menggunakan teknologi informasi yang semaikin berkembang. Komitmen dan ketentuan yang ditetapkan oleh pimpinan organisasi tentang pengelolaan pengembangan kualitas tenaga KB melalui E-learning tersebut merupakan sumber kekuatan hukum atau dukungan organisasi terhadap pengembangan E-learning dalam program KB sehingga tidak ada kesulitan bagi komponen pelatihan untuk memanfaatkan sumber daya yang tersedia maupun peluang untuk memenuhi kebutuhan pengembangan E-learning.

\section{Tujuan Pengembangan E-learning bagi Petugas Lapangan}

Dilihat dari rumusan tujuan $E$ learning dua versi sebagaimana ditetapkan dalam SK Kepala BKKBN tahun 2008 dan 2010 tentang E-learning, kiranya perlu ada peninjauan kembali. Tampak ada tumpang tindih apabila dilihat dari aspek pembelajarannya. Bagaimanapun komponen Pelatihan bertanggung jawab atas fungsi pembelajaran di lingkup program KB sehingga apabila isu pokoknya E-learning, maka Pusat Pelatihan merupakan pemeran inti tentang pembelajaran berbasis web yang memerlukan dukungan teknis dari Direktorat Teknik sebagai penyedia jaringan dan sarana, sedangkan Direktorat Informasi sebagai penyedia layanan yang terkait dengan teknologi informasinya. Analisis ini tidak akan berbeda pemanfaatannya apabila akan terjadi perubahan struktur organisasi sebagai konsekuensi lahirnya

Keputusan Presiden terbaru tentang lembaga KB karena inovasi pembelajaran 
berbasis teknologi informasi ini tetap melekat pada siapapun pemegang fungsi pembelajaran tenaga KB. Selain itu, Pedoman yang disusun merupakan cerminan pembagian kelompok kerja yang dibentuk berdasarkan tugas fungsi tiap komponen terkait. Dari pendekatan berdasarkan tugas fungsi tiap komponen tersebut menjadi jelas bahwa pendekatan tim yang dilakukan tidak berbeda dengan pengembangan program pembelajaran konvensional. Sebagaimana prinsip-prinsip dasarnya, pembelajaran dengan berbasis komputer dan web bukanlah pembelajaran konvensional. Ia memerlukan strategi pengembangan dan pembelajaran yang berbeda. Satu tim terdiri dari tenaga inti teknologi informasi dan teknis jaringan, tenaga inti teknologi pembelajaran dan media, subject matter expert $(S M E)$ yang mewakili substansi serta tenaga inti politis administratif yang mewakili pengambilan keputusan dan pendanaan.

\section{Rasional Pengembangan E-learning bagi Petugas Lapangan}

Beberapa Rasional mengapa Elearning dikembangkan, utamanya sebagai berikut. Pertama, dalam era desentralisasi diperlukan perubahan pola pikir dari pemimpin dan staf serta stakeholdernya. Komitmen pemerintah daerah untuk meningkatkan dan membina kualitas SDM KB sangat bervariasi, bahkan sebagian besar masih di bawah standar yang diperlukan. Oleh karena itu, dibutuhkan pendekatan baru dalam sistem pembelajaran dengan memanfaatkan teknologi informasi dan ketersediaan infrastruktur yang semakin meningkat. Kedua, alasan geografis dan demografis. Program KB sebagaimana program pembangunan yang lain, dihadapkan pada kondisi geografis yang sulit sehingga dengan sistem desentralisasi diharapkan pengelolaan program lebih dimudahkan. Demikian pula alasan demografis, program KB secara rasional seharusnya memiliki Petugas Penyuluh KB setiap dua desa minimal satu petugas; yang jumlahnya seharusnya menjadi setengah jumlah desa (lebih dari 60.000 desa) yaitu 30.000 petugas. Sebagai catatan sebelum desentralisasi jumlah tersebut bahkan telah mencapai 40.000 . Saat ini tinggal 20.000 lebih. Petugas Penyuluh KB dan petugas lini lapangan lain yang jumlahnya puluhan ribu harus terus menerus dibina agar kualitasnya terjaga.

Ketiga, Manajemen Sistem Informasi (MSI) berbasis komputer sudah dikembangkan sejak 2 dekade yang lalu. Sejak tahun 1970 BKKBN didirikan, telah disadari bahwa menghasilkan, menganalisis, dan menggunakan informasi adalah elemen yang penting untuk keberhasilan program. Pengembangan infrastruktur MSI ini terus ditingkatkan dari tahun ke tahun sehingga diharapkan siap memfasilitasi sistem pembelajaran yang akan dikembangkan. Keempat, kerjasama dan pembagian biaya antara Pemerintah Pusat-Daerah dan sponsor lain dalam memberikan bantuan, masih perlu dieksplorasi lagi. Kolaborasi dapat dieksplorasi dengan Kementerian Pendidikan Nasional di tingkat pusat dan juga tingkat daerah atau kecamatan, Pustekom, dan UT. Belakangan dengan 
kantor Menkominfo. Berdasarkan keempat rasional di atas tampak pengembangan E-learning telah teruji memperoleh dukungan lingkungan yang secara nyata dapat dilihat manfaat pengembangannya. Namun, upaya untuk selalu dalam dukungan politis dan fisik harus terus ditingkatkan.

Kelima, tidak kalah penting dalam konteks pembelajaran jarak jauh ini adalah membangun budaya organisasi untuk menumbuh-kembangkan kesadaran petugas lapangan agar dapat belajar secara mandiri. Data yang diperoleh tentang budaya belajar mandiri memperlihatkan bahwa dengan adanya program organisasi belajar bagi petugas lapangan KB yang lebih sering disebut dengan program Reposisi bagi Petugas Lapangan KB telah berhasil membangun budaya belajar mandiri. Namun demikian program ini tidak berkesinambungan. Budaya organisasi termasuk budaya belajar sangat berperan bagi organisasi dalam mengelola satu perubahan maupun mengadopsi satu ide dan teknologi baru. Ia bukan sesuatu yang ada dalam organisasi tetapi sesuatu yang perlu dibangun dan dipupuk sebagai lahan subur satu pertumbuhan organisasi untuk menjadi organisasi yang senantiasa berkembang kearah yang terbaik.

\section{Evaluasi Input (Input Evaluation)}

Evaluasi input yang dikaji dalam penelitian ini meliputi perencanaan sumber daya manusia (SDM) baik kualifikasi peserta maupun pengembang dalam pengembangan E-learning, sistem diklat dalam pengembangan $E$ learning, prosedur pengembangan dan pelaksanaan E-learning, perencanaan sarana dan prasarana, serta anggaran pengembangan dan pelaksanaan Elearning. Gold dalam Aydm (2005: 257) memperingatkan bahwa harus berhatihati dalam proses adopsi E-learning untuk suatu organisasi, ia menegaskan adopsi E-learning tanpa perencanaan yang cermat kemungkinan besar akan berakhir dengan cost overruns, produk pembelajaran yang tidak menarik, dan kegagalan.

\section{Kajian Sumber Daya Manusia}

Peserta program E-learning ini adalah Penyuluh Keluarga Berencana (PKB) dan Petugas Lapangan Keluarga Berencana (PLKB). Analisis kebutuhan telah dilakukan kepada petugas lapangan (PKB/PLKB) sebagai responden utama. Pengelola KB tingkat provinsi, Pengelola KB tingkat Kabupaten/Kota, dan Pengelola Pelatihan KB sebagai responden pendukung. Data yang diperoleh dari analisis kebutuhan tersebut ternyata lebih banyak petugas lapangan sudah menggunakan komputer, namun diantara yang sudah menggunakan komputer lebih banyak petugas belum menggunakan internet dibandingkan dengan yang sudah. Hampir semua responden belum mengetahui tentang pembelajaran E-learning. Untuk itu, mereka telah diberi pelatihan dasar komputer (microsoft office application baik word maupun powerpoint) bagi petugas lapangan yang belum pernah sama sekalimenggunakan komputer dan memberikan orientasi tentang pembelajaran melalui E-learning yang akan mereka peroleh. Selain itu, terkait dengan budaya belajar mandiri, diperlukan 
pelatihan tentang organisasi belajar dan pengelolaan aplikasi organisasi belajar pada lingkungan kerja mereka.

Begitu cepatnya perkembangan pembelajaran berbasis teknologi, baru saja praktisi dan pelatih terbiasa dengan pembelajaran dengan menggunakan media elektronik, lingkungan pembelajaran sudah berubah lagi. Munculnya Internet dan pelatihan berbasis Web membuat orientasi pembelajaran harus menyesuaikan lagi dengan perubahan yang lebih kental dengan penggunaan teknologi komputer. Satu loncatan bagi sistem pembelajaran dalam program KB yang langsung menggunakan teknologi komputer dan Web tanpa pengalaman penggunaan teknologi yang cukup bermakna dalam pembelajaran KB sebelumnya. Perkembangan yang kurang menguntungkan ini menjadikan kurangnya tenaga ahli di bidang media dan teknologi dalam pembelajaran di dalam lingkungan KB sebagai kendala yang cukup mengganggu dalam pengembangan E-learning dalam pembelajaran KB yang sedang berlangsung.

Membangun tim yang solid untuk merencanakan pelatihan berbasis teknologi dan web adalah satu langkah awal yang akan menentukan keberhasilan program pembelajaran yang akan dibangun. Menyatukan orangorang yang profesional di bidangnya akan memberikan kontribusi secara signifikan. Sebaliknya, menyatukan atau mendayagunakan mereka yang tidak kompeten dapat mengakibatkan kelambatan, kebingungan, dan konflik internal bahkan sampai pada tidak tercapainya tujuan program (Jolliffee, dkk, 2001: 70). Itulah sebabnya, sedini mungkin sebelum desain dibuat, sangat penting untuk memberikan perhatian terhadap penataan "staf" dengan memberikan perimbangan terhadap profesional dan pengalaman. Memadukan tim web yang solid memang tidak mudah namun bagaimanapun harus dipersiapkan sejak awal. Kondisi yang tidak siap dengan tim yang dilengkapi dengan pembagian tugas dan peran dalam pengembangan dan pelaksanaan dapat dengan mudah terlihat pada objek E-learning yang saat ini sedang dievaluasi.

\section{Identifikasi Kemampuan Sistem Dik- lat}

Apakah sistem yang ada mampu membawakan tugas dan fungsi yang semakin berat? ketika diperlukan penataan Sistem Diklat, maka diperlukan penataan Sistem Diklat pembelajaran berbasis teknologi informasi web. Pendekatan pembelajaran sesuai dengan perkembangan teknologi belum disesuaikan. Dalam kondisi lingkungan seperti itu kebutuhan mengatasi masalah kekurangterampilan SDM dalam era desentralisasi harus diatasi dengan membangun Diklat Stratejik yang di dalamnya antara lain terdapat faktor teknologi informasi yang harus dipertimbangkan dalam strategi pembelajarannya. Pada saat program KB sedang menghadapi perubahan garapan dimana Kependudukan menjadi salah satu tanggung jawab lembaga ini di samping KB dan KS, maka Diklatpun memperluas cakupan sasaran diklatnya. Susunan struktur organisasi yang telah mengantisipasi perubahan itu 
sudah seharusnya segera diikuti dengan mengidentifikasi jenis dan jumlah tenaga yang memerlukan penyiapan dan peningkatan kualitasnya. Begitu juga Sistem Diklat harus segera direviu apakah masih cukup mampu menjalankan tugas dan fungsinya, serta selanjutnya merupakan kajian sistem yang masih banyak lagi faktor penentu dan kendala agar berhasil melakukan tugas dan fungsi yang dibebankan oleh organisasi.

\section{Prosedur Pengembangan E-learning}

Terkait dengan upaya menguji pendekatan yang relevan dalam prosedur pengembangan E-learning, sebaiknya digunakan pendekatan yang telah teruji secara ilmiah. Terkait kebutuhan itu, Joliffee (2001:75) menambahkan ada tiga langkah dalam pengembangan bahan ajar dalam E-learning, dapat diuraikan sebagai berikut. Pertama, menetapkan strategi pembelajaran. Tahap ini harus menetapkan bagaimana pembelajar belajar dari bahan-bahan yang disajikan untuk dapat mencapai tujuan pembelajaran, pemelajar diberi paparan informasi, berinteraksi dengan aspek tertentu dari bahan ajar dan melakukan berbagai kajian. Mereka juga perlu melakukan penilaian (assesment) dan berkomunikasi dengan pihak lain termasuk fasilitator dari kegiatan belajar. Strategi pembelajaran menjelaskan bagaimana pemelajar mencapai tujuan kinerja.

Ada lima kegiatan dalam strategi pembelajaran. Pertama, kegiatan pra pembelajaran yang mencakup perhatian pemelajar dan memberi pengantar kegiatan belajarnya. Di sini tujuan di- tetapkan dan dibuat menarik untuk mengungkap pengetahuan awal pembelajar. Kedua, presentasi informasi, disini materi diatur urutan (sequence) dan strukturnya disesuaikan untuk pembelajar. Ketiga, praktek, kegiatan yang mendorong pemelajar mengaplikasikan pengetahuan yang telah dipelajari. Feedback harus diberikan terhadap kinerja pada setiap kegiatan. Keempat, assesment hasil belajar yang terdiri dari evaluasi formatif dan sumatif serta pre-test dan post test. Kelima, follow up - remediasi.

Kedua, menetapkan desain. Tahap ini ditetapkan sebagai sarana (tools) yang diperlukan untuk memfasilitasi pemelajar menyelesaikan berbagai kegiatan sebagai bagian dari bahan ajar.

Ketiga, menetapkan standar bahan ajar. Apakah seseorang yang mengembangkan kegiatan belajar berbasis web atau anggota dari satu tim besar yang mengembangkan satu kegiatan skala besar berbasis web, proyeknya akan membutuhkan teknik dokumentasi dan panduan pembelajaran. Agar kegiatan pembelajaran dalam E-learning layak dan memenuhi kebutuhan yang diinginkan, ia harus memenuhi standar dalam aspek rambu-rambu isi (content) dan lay out serta rambu-rambu proses pengembangan dan pengelolaannnya. (1) Pada rambu-rambu content dan lay out, ia menetapkan parameter dan standar yang diacu dalam produksi dan penyajian bahan ajar. (2) Pada panduan atau rambu-rambu proses, ramburambu ini harus ditetapkan sebagai acuan pengembangan dan pengelolaan bahan ajar. (3) Pembelajaran berbasis web harus mempertimbangkan bebe- 
rapa isu penting: adanya berbagai tipe komputer, operating system, dan web browser yang digunakan. Ada isu crossplatform compatibility yang harus diperhatikan. (4) Panduan pembelajaran perlu dipersiapkan agar bahan ajar memenuhi standar. Panduan bisa dibuat sendiri atau mengambil dari standar pembelajaran yang sudah ada. Untuk mengetahui prosedur pengembangan yang dilakukan, tidak ditemukan informasi yang cukup signifikan untuk memastikan apakah prosedur pengembangan E-learning yang sudah ada sudah sesuai dengan langkah-langkah pengembangan sebagaimana standar pengembangan yang ada.

Menurut Mayer (2002), terdapat 10 prinsip desain multimedia pembelajaran yang harus diperhatikan, yaitu (1) prinsip multimedia: orang belajar lebih baik dari gambar dan kata dari pada sekedar kata-kata saja; (2) prinsip kesinambungan spasial: orang belajar lebih baik ketika kata dan gambar terkait disandingkan berdekatan dibandingkan apabila disandingkan berjauhan atau terpisah; (3) prinsip kesinambungan waktu: orang belajar lebih baik ketika kata dan gambar terkait disajikan secara simultan dibandingkan apabila disajikan bergantian atau setelahnya; (4) prinsip koherensi: orang belajar lebih baik ketika kata-kata, gambar, suara, video, dan animasi yang tidak perlu dan tidak relevan tidak digunakan; (5) prinsip modalitas: orang belajar lebih baik dari animasi dan narasi (termasuk video), daripada dari animasi plus teks pada layar; (6) prinsip redudansi: orang belajar lebih baik dari animasi dan narasi (termasuk video), daripada dari animasi, narasi plus teks pada layar (redundan); (7) prinsip personalisasi; orang belajar lebih baik dari teks atau kata-kata yang bersifat komunikatif (conversational) daripada kalimat yang lebih bersifat formal; (8) prinsip interaktivitas: orang belajar lebih baik ketika ia dapat mengendalikan sendiri apa yang sedang dipelajarinya (manipulatif: simulasi, game, branching); (9) prinsip sinyal: orang belajar lebih baik ketika kata-kata, diikuti dengan cue, highlight, penekanan yang relevan terhadap apa yang disajikan; (10) prinsip perbedaan individual: menggunakan multimedia (kombinasi antara teks, gambar, grafik, audio/narasi, animasi, simulasi, video) secara efektif untuk mengakomodir perbedaan modalitas belajar (visual, auditori, dan kinestetik).

Pengujian terhadap prosedur dan prinsip pengembangan program Elearning pada materi penggerakan masyarakat dan demografi dengan mengacu pada 10 prinsip desain multimedia pembelajaran, hasilanalisisnya dapat dideskripsikan sebagai berikut. (1) Pada materi penggerakan masyarakat sudah memperhatikan prinsip multimedia, namun pada materi demografi belum. (2) Pada materi penggerakan masyarakat sudah memperhatikan prinsip kesinambungan spasial, namun pada materi demografi belum. (3) Belum memperhatikan prinsip kesinambungan waktu. (4) Pada materi penggerakan masyarakatsudah memperhatikan prinsip koherensi, namun materi pada demografi belum. (5) Belum memperhatikan prinsip modalitas. Tidak ada animasi dan narasi (termasuk video), yang ada hanya animasi sederhana dan teks 
pada layar. (6) Belum memperhatikan prinsip redudansi. Pada program ini hanya terdapat gambar, teks, dan animasi sederhana dan belum menggunakan animasi dan narasi (termasuk video). (7) Belum memperhatikan prinsip personalisasi dalam bahasa yang digunakan. (8) Sudah memperhatikan prinsip interaktivitas dalam skala terbatas karena masih belum ditemukannya interaktivitas dalam bentuk simulasi, game atau branching. (9) Belum memperhatikan prinsip sinyal karena tidak adanya cue, highlight, penekanan yang relevan terhadap apa yang disajikan. (10) Belum memperhatikan prinsip perbedaan individual karena dalam program ini hanya mencakup gambar, teks, dan animasi sederhana. Program ini belum meng-gunakan grafik, audio/ narasi, simulasi, serta video sehingga belum mengakomodir perbedaan modalitas belajar terutama auditori dan kinestetik.

\section{Prosedur Pelaksanaan E-learning}

Perencanaan, sosialisasi, pengorganisasian, dan pengendalian teknis Elearning diatur melalui Peraturan Kepala Badan Koordinasi Keluarga Berencana Nasional, analisis terhadap mekanisme perencanaan pelaksanaan Elearning yang diatur dalam pedoman tersebut, analisisnya sebagai berikut. (1) Tidak dibuat forum khusus untuk sosialisasi sekaligus mereview program E-learning. (2) Dalam mengendalikan teknis pelaksanaan E-learning lebih difokuskan pada kesiapan widyaiswara dan jadwal pembelajaran sementara kesiapan peserta, sistem jaringan dan ketersediaan sarana lokal kurang men- dapatkan perhatian (3) Ditemukan kurangnya keterampilan tim penilai angka kredit tentang teknis pemberian penilaian angka kredit. (4) Akibat dari rumitnya pengisian formulir penilaian, banyak ditemui kelambatan proses penetapan angka kredit.

\section{Sarana dan Prasarana}

Dari temuan diperoleh kesenjangan antara kebutuhan sarana dan prasarana dengan ketersediaannya. Ada temuan proses belajar online tidak berlangsung atau terhambat karena kurang siapnya dukungan teknis sarana dan prasarana.

\section{Anggaran Pengembangan dan Pelak- sanaan E-learning}

Pada awalnya tidak ada anggaran secara khusus dan terstruktur dalam pengembangan dan pelaksanaan Elearning untuk jangka panjang, baru pada tahun 2009 mulai dianggarkan dana untuk untuk pengembangan dan uji coba E-learning. Pada tahun 2010 terdapat anggaran untuk pelaksanaan pada beberapa daerah.

\section{Evaluasi Proses (Process Evaluation)}

Evaluasi proses dalam penelitian ini meliputi kesesuaian antara pelaksanaan kualifikasi SDM (peserta dan pengembang) dan perencanaannya, kesesuaian antara pelaksanaan E-learning dengan perencanaannya, kesesuaian anggaran dan jadwal dalam pengembangan dan pelaksanaan E-learning.

\section{Kajian Sumber Daya Manusia}

Kesesuaian Kualifikasi Peserta. Dalam proses pelaksanaannya semua peserta yang menjadi responden pada proses 
pengembangan E-learning (PKB/PLKB) sudah memenuhi persyaratan karena peserta yang awalnya belum memahami tentang program pembelajaran jarak jauh melalui E-learning sudah mengikuti pelatihan komputer dasar dan pelatihan tentang pembelajaran melalui E-learning. Namun, dalam mempertahankan konsistensi motivasi belajar, isu pengelolaan angka kredit yang terkait dengan hasil belajar masih belum berjalan lancar karena kurang mampunya pengelolaan angka kredit melaksanakan penilaian yang materinya sangat rinci. Sebagaimana telah dibahas sebelumnya bahwa motivasi belajar dengan E-learning sangat dipengaruhi oleh manfaat hasil belajar terhadap meningkatnya angka kredit petugas lapangan KB.

Kesesuaian Kualifikasi Pengembang. Pada pelaksanaannya pengembang yang diberdayakan adalah widyaiswara sebagai narasumber materi (ahli materi) dan pengembang media. Berdasarkan pengamatan terhadap program E-learning pada materi Demografi dan Penggerakan Masyarakat, pengembang media belum memiliki kemampuan untuk mengembangkan multimedia interaktif karena media yang dikembangkan belum mengikuti prinsip-prinsip pengembangan multimedia interaktif. Secara keseluruhan karena sangat luasnya organisasi pengembang dan pelaksana, serta kurangnya tenaga profesional yang mengawal secara terus-menerus pengembangannya, maka banyak kendala yang ditimbulkan. Oleh karena kualifikasi pengembang yang belum terpenuhi, konsekuensinya perlu perbaikan pada tahap perencanaan.

Kesesuaian antara Pelaksanaan Elearning dan Perencanaan E-learning

Dukungan Teknis Infrastruktur, Sarana dan Kolaborasi. Adanya kendala di bandwidth ketika mendownload program semua drop (gagal) karena hanya tersedia $1 M B$ sedangkan untuk interaktif dibutuhkan $8 \mathrm{MB}$ sehingga audio dalam multimedia tidak bisa digunakan dan hanya fokus pada narasi dan grafis sederhana saja. Setelah konfirmasi dengan staf Direktorat Teknik ditemukan bahwa masalah jaringan tidak hanya di Pusat saja, kemungkinan besar juga merupakan kendala lokal. Artinya apa yang di persepsikan oleh pengembang bahwa gagalnya komunikasi interaktif disebabkan karena tidak cukupnya dukungan bandwidth, ternyata tidak sepenuhnya sebagai satu-satunya penyebab. Kemungkinan kemampuan bandwidth lokal lah yang bermasalah. Temuan lain, ada ketidaksesuaian antara kajian pada tahap perencanaan yang telah mempersiapkan kemampuan kapasitas server dan bandwidth serta kebijakan akan pemenuhan sarana yang diperlukan dengan pelaksanaannya. Banyak kendala terkait dengan dukungan teknis jaringan dan teknologi informasi. Dari temuan terbukti bahwa dalam pengembangan E-learning tenaga-tenaga yang profesional di bidangnya harus dipenuhi sehingga setiap kendala teknis yang dihadapi segera dapat terdeteksi akar masalahnya.

Dalam kaitan kolaborasi jaringan, telah diperoleh gambaran untuk kemungkinan bekerjasama dengan Jar- 
diknas dan Telkom juga Indosat yang perlu ditindaklanjuti. Dengan Menkominfo yang telah membangun jaringan sampai ke tingkat kecamatan, tampaknya penjajagan dengan lembaga tersebut akan menjadi hubungan yang prospektif. Dari pembahasan dengan Direktorat Teknik, kerjasama dengan Microsoft akan dilakukan pada tahun 2011 untuk Aplikasi E-learning. Memorandum of Understanding ( $M O U$ ) dengan Microsoft sudah disepakati sejak tahun 2008. Kerjasama dalam Aplikasi baik hardware maupun software akan menggunakan Government Lisence sehingga harga akan lebih rendah. Kemungkinan lain perlu juga diantisipasi yakni isu Pengolahan dan sewa server, bandwidth melalui Inovasi Cloud Computing. Harapannya dengan kerjasama semacam ini kecepatan dan kualitas proses pembelajaran akan terjamin. Perkembangan bentuk kerjasama semacam ini kiranya perlu segera dipelajari dan dimanfaatkan kalau memang memberi manfaat.

Rencana dan Pelaksanaan Jadwal. Kendala lain adalah terbatasnya waktu untuk belajar karena kesibukan para PKB/PLKB. Kendala lain pada saat widyaiswara online untuk memberikan konsultasi pada peserta melalui 'chatting' ternyata dukungan infrastruktur dan sarana lain tidak mencukupi. Demikian juga, seringkali email yang dikirimkan oleh peserta tidak sampai kepada widyaiswara. Masih banyak masalah teknis yang perlu diatasi karena masalah infrastruktur dan sarana lokal yang harus diperhitungkan, serta di pusat sendiri dimana dukungan teknis masih harus dipantau secara terus menerus.
Masalah Koordinasi di Lapangan. Pelaksanaan kebijakan Pimpinan dalam peningkatan server dan bandwidth sesuai kebutuhan belajar, ternyata masih ada kendala karena belum adanya pemahaman bahwa program pembelajaran memerlukan infrastruktur lebih dibandingkan dengan program layanan informasi lain yang tidak memerlukan hubungan interaktif dengan sasaran. Pengalokasian bandwidth berdasarkan urgensi dan prioritas perlu ditata kembali diantara para pengguna yang ada termasuk unit Pelatihan yang akan mengelola E-learning. Program pembelajaran ini telah disosialisasikan melalui forum nasional dan internasional tahun 2007, sebagai satu program inovatif yang sangat sarat dengan kemampuan mengaplikasikan kaidah keilmuan. Diperlukan satu tim lintas fungsi yang sebenarnya lebih mementingkan kemampuan anggota tim secara individu dan benar-benar profesional jadi bukan representasi dari fungsi-fungsi organisasi.

Masalah koordinasi akan berjalan baik apabila persepsi yang sama terhadap pembelajaran E-learning telah tercapai. Apabila pihak-pihak terkait dengan pengembangannya masih memiliki persepsi yang berbeda terhadap hakikat pembelajaran E-learning bagi petugas lapangan, maka kegalauan terhadap kendala dukungan komitmen dari beberapa pihak akan terus berlangsung. Dalam pengaturan strategi pembelajaran pada pelatihan-pelatihan yang menggunakan teknologi berbasis web dan internet ini masih harus menggunakan pendekatan tatap muka dan metode pembelajaran yang tepat untuk 
mencapai tujuan pembelajaran yang menghendaki kemampuan motorik dan perubahan sikap perilaku bagi pemelajarnya. Dibutuhkan sistem pelatihan nasional yang mengakomodasi kebutuhan pembelajaran dengan memanfaatkan teknologi yang semakin berkembang serta wawasan lokal, nasional, dan global untuk akses kerjasama dan dukungan sumber daya.

\section{Kesesuaian Anggaran dan Jadwal dalam Perencanaan dan Pelaksanaan E-learning}

Pada tahun 2009 alokasi anggaran untuk pengembangan dan uji coba $E$ learning telah dilaksanakan sesuai dengan rencana anggaran namun demikian pada tahun 2010 masih ada beberapa daerah yang masih dalam tahap uji coba E-learning sehingga terjadi pergeseran jadwal dan alokasi anggaran. Seharusnya dibuat grand strategi untuk jangka waktu lima tahun kedepan sehingga anggaran dana dapat dialokasikan secara efektif dan efisien.

\section{PENUTUP}

\section{Kesimpulan}

Evaluasi Konteks. Terkait dengan evaluasi konteks, berdasarkan hasil penelitian dan pembahasan dapat disimpulkan bahwa dengan telah ditetapkannya surat keputusan dan peraturanperaturan pendukungnya landasan pengembangan E-learning bagi petugas lapangan KB yang merupakan sumber hukum yang menaungi legalitas, tujuan, serta hubungan kerja telah ada. Demikian pula pengembangan E-learning telah mempunyai tujuan, sasaran, dan jangkauan yang jelas. Dasar per- timbangan (rasional) mengapa E-learning dikembangkan dan berbagai faktor yang menunjukkan kesiapannyapun telah teridentifikasi. Namun demikian, diperlukan ketentuan yang mengatur bahwa E-learning menjadi inti kegiatan yang dilakukan oleh bidang Pelatihan, didukung oleh teknis jaringan dan informasi, yang merupakan dasar hukum dan kebijakan agar pusat pelatihan mampu mengelola strategi pem-belajaran dengan menggunakan teknologi informasi yang semakin berkembang.

Evaluasi Input. Berdasarkan hasil analisis data dan pembahasan terhadap komponen input dapat disimpulkan bahwa organisasi belajar yang pernah diprogram melalui kegiatan Reposisi petugas lapangan tidak berlanjut sebagai program yang berkesinambungan yang berpengaruh terhadap pembangunan budaya belajar mandiri; peluang untuk mengaplikasikan pembelajaran berbasis web dalam program KB dengan efektif ditentukan oleh kemampuan sistem diklat dalam mengakomodasikan tugas fungsi baru yang dibebankan. Identifikasi kemampuan sistem diklat belum dilakukan; ditemukan perencanaan sarana dan prasarana serta anggaran yang tidak sesuai dengan kebutuhan; ditemukan banyak ketidaksesuaian antara prosedur pengembangan yang dilakukan oleh tim pengembang dengan standar dan prinsip-prinsip prosedur pengembangan yang ada; dan kolaborasi dalam kaitan dengan jaringan, telah dilakukan eksplorasi kerjasama dengan Jardiknas, Telkom, dan Menkominfo. Tahun 2011 akan dilaksanakan kerjasama untuk Aplikasi E-learning dengan Microsoft. 
MOU dengan Microsoft telah disepakati sejak tahun 2008.

Evaluasi Proses. Berdasarkan hasil analisis data dan pembahasan terkait komponen proses dapat disimpulkan bahwa: kesesuaian kualifikasi peserta E-learning telah memenuhi persyaratan kemampuan komputer dasar dan telah memahami program pembelajaran jarak jauh melalui E-learning. Namun karena terhambatnya proses penilaian angka kredit, hal ini berpengaruh terhadap motivasi belajar peserta; kesesuaian kualifikasi pengembang belum memenuhi kebutuhan baik kualitas maupun kuantitas khususnya pada pengembang multimedia; terdapat ketidaksesuaian antara kebutuhan prasarana khususnya kapasitas server dan bandwidth yang telah direncanakan dengan kebutuhan sebenarnya pada saat pelaksanaan; penyesuaian jadwal sesuai dengan peluang yang tersedia dalam program E-learning, sering tidak didukung oleh kesiapan sarana dan infrastruktur yang memadai. Koordinasi di lapangan terkait dengan pengalokasian bandwidth berdasarkan prioritas belum tertata dengan baik; dan tim pengembang dan pelaksana disusun berdasarkan representasi fungsi-fungsi organisasi yang sering kurang efektif.

\section{Saran}

Evaluasi Konteks. Perlu peninjauan kembali tugas kewenangan Pengembangan dan Pengelolaan E-learning oleh bidang yang mempunyai fungsi Pendidikan dan Pelatihan KB.

Evaluasi Input. Budaya belajar mandiri masih perlu terus dibangun. Proses regenerasi terus berlangsung sehingga diperlukan perencanaan yang cerdas dalam mempersiapkan kualitas petugas lapangan dan pejabat baru. Organisasi Belajar maupun Knowledge Management merupakan tantangan untuk dapat terus diupayakan. Sebagai konsekuensi diaplikasikannya pendekatan baru yang berdampak sistemik maka perlu dilakukan upaya identifikasi kemampuan sistem diklat yang ada terhadap perubahan yang terjadi. Perlu dibuat perencanaan sarana, prasarana, dan anggaran sesuai dengan kebutuhan. Untuk memperoleh solusi pendekatan yang relevan dalam prosedur pengembangan telah disarankan untuk dipertimbangkan langkah-langkah strategi pembelajaran dalam Elearning, desain, dan penetapan standar bahan ajar.

Evaluasi Proses. Motivasi belajar peserta E-learning merupakan faktor yang berpengaruh terhadap hasil belajar. Oleh karenanya hambatan perolehan angka kredit perlu segera diatasi dengan mengupayakan peningkatan keterampilan pengelola dalam melakukan penilaian angka kredit petugas lapangan KB yang sangat terperinci. Pengadaan tenaga yang mampu mengembangkan pembelajaran dengan berbasis web dengan multimedia, sudah sangat diperlukan. Kerjasama dengan Perguruan Tinggi atau lembaga yang lebih berpengalaman perlu dijajagi untuk kebutuhan jangka panjang. Peninjauan kembali perencanaan akan kemampuan kapasitas server dan bandwidth baik di pusat maupun lokal perlu memperoleh perhatian dari pimpinan maupun para manajer. Perlu sinkronisasi jadwal dan tim teknis baik di pusat 
maupun lapangan untuk menghindari terhambatnya proses belajar yang sangat mungkin berdampak pada menurunnya motivasi belajar peserta E-learning. Koordinasi di lapangan akan terganggu apabila masalah yang mendasar tentang pengalokasian bandwidth berdasarkan prioritas tidak segera diatasi. Kebijakan pimpinan tentang isu ini akan sangat membantu. Tim Pengembang dan Pelaksana E-learning perlu disusun, terdiri dari tenaga-tenaga profesional di bidangnya serta ditetapkan berdasarkan nama/individu untuk periode waktu tertentu.

\section{UCAPAN TERIMA KASIH}

Penulis mengucapkan terima kasih kepada Redaktur dan Staf Jurnal Cakrawala Pendidikan Universitas Negeri Yogyakarta yang telah memberi input dan mimbar agar artikel ini dapat dijadikan sebagai bahan diskusi bagi pembaca.

\section{DAFTAR PUSTAKA}

BKKBN. 2010. Pengelolaan Pengembangan Kapasitas Tenaga Program Keluarga Berencana dan Keluarga Sejahtera di Kabupaten dan Kota melalui E-learning. Jakarta: BKKBN.

BPS. 2007. Survei Demokrasi dan Kesehatan Indonesia. Jakarta: BPS.
Gilley, W. J. and Maycunich, Ann. 2000. Beyond The Learning Organization. New York: Perseus Books Group.

Jolliffee, A., Jonathan R. and David S. 2001. The Online Learning Handbook: Developing and Using WebBased Learning. London: Kogan Page Limited.

Mayer, R. E. 2001. Multimedia Learning. New York: Cambridge University Press, http:/fakultasluarkampus.net/wp-contentuploads/2010/06/10-Prinsip-Desain-Multimedia-Pembelajaran.pdf diakses tanggal 25 November 2010.

Miarso, Yusufhadi. 2004. Menyemai Benih Teknologi Pendidikan. Jakarta: Prenada Media.

Senge, P. M. 1990. The Fifth Discipline. New York: Bantam Doubleday Dell Publishing Group, Inc.

Stufflebeam, D. L. and Anthony J. Shinkfield. 2007. Evaluations Theory, Models, and Applications 1st Edition. San Fransisco: JosseyBass. 